\title{
THE TRADITION OF LIVING OF MUSLIM COMMUNITY KUDUSKULON
}

\author{
Atiek Suprapti, Agung BudiSardjono, H. Arnis Rochma and N.F. Yasmina
}

Department of Architecture, Diponegoro University Semarang, Indonesia

Received 2013-12-28; Revised 2014-06-22; Accepted 2014-07-07

\begin{abstract}
The northern coast of Java island Indonesia inherited old cities that hold important role in the spread of Islam. It has a strong correlation with the legend of Walisanga that were acted around the 16th century. The Ancient city of Kudus plays an important role in spreading Islam in the coastal line of Java. Kudushas witnessed the glory of the first Islamic Sultanate in Java. Sunan Kudus was very skillful in transforming Hindu teachings into Islamic teachings. They developed a settlement on the west side of Gelis River, thus the name "Kudus Kulon" (West Kudus). The social-economy independence of Kudus makes it relatively stable to change. The ethnical dynamics of coastal cities have major influence in the Muslim settlement in Kudus Kulon, this is visible from, among them, the building orientations and the spatial arrangement. However, the pressure of modernization-capitalization of the surrounding neighborhood results to several changes. This review is necessary considering the tradition of living of the Muslim community in that city has been here for centuries and has been the identity of the environment. The research will contribute to enrich to the architectural theory especially for a place of local wisdom. The locus of this research is in KampungKauman Kudus Kulon. The research method is historical and ethnographic. The purpose of this research is to understand the theme of tradition of living in the Muslim community of Kudus Kulon. The result of the research is the four concepts include: (1) Center and Orientation, (2) Controlled access; (3) Space of agreements; and (4) High level privacy. The changes that happen in the elements that fill the spaces caused by the shift of idealism as a result of the demanding situation. This result is beneficial to the strengthening of the local identity.
\end{abstract}

Keywords: Tradition of Living, Settlement, Kudus Kulon

\section{INTRODUCTION}

The Northern Coastal area of island of Javais written in the history as the entrance gate for any cultural influence from outside of Java (Wertheim, 1999). One of the very significant influences is the Islamic teaching brought here by the merchants of India, Persia and China. One of the criteria that is phenomenal in that particular history is the act of Walisanga (nine saint) in the process of spreading Islam. The propaganda in Central Java reached its climax in the 15 th century with the erection of Demak Sultanate, which was the first Islamic Kingdom in Java. Demak-Jepara-Kudus were the areas with very important roles in the series of Islamic propaganda in Java (Wertheim, 1999; Tjandrasasmita,
2000; Lombard, 2005). The acculturation process which then became the way in for Islam in Java was then known as "Javanese Islam" (Qurtuby, 2003).

Muslim settlement is marked with the following functions: Household settlements, markets, madrasah (Islamic school) and prominent mosques or religious buildings (Ekomadyo, 1999). The life of coastal community is more open to creating relationship with outer circle and is familiar with trading activities, making the economy life more prosperous (Suprapti, 2008; Suprapti and Budihardjo, 2010; Suprapti, 2012). The life of economy-social-cultural-religious seem to stand out more among the synergy of business success that is based on familiarity, that is allocated to support religious propaganda and combined with prosper social Corresponding Author: Atiek Suprapti, Department of Architecture, Diponegoro University Semarang, Indonesia 
life (Suprapti, 2008; Suprapti and Budihardjo, 2010; Suprapti, 2012). Tradition is the inherited habit that is still conducted in the society. Tradition is also judgment or assumption that the ways people have been living is the best and the rightest way to live. These traditions are, among all: Inheriting traditional house, respecting 'pepunden' (ancestor), santri life, obeying Kyai (religious teacher of Islam), protecting women and children. These tradition still stand strong among the changes caused by the development of science and technology.

The purpose of this research includes: (1) The mapped-out themes of the tradition of living (2) the explained changes that happen in the settlements and (3) the explained meaning in living space of Kudus Kulon.

\section{MATERIALS AND METHODS}

\subsection{Muslim Settlement Kudus Kulon}

Traditional cities in Java coast grow and develop under the influence of Islamic teaching. They also have strong philosophy from the culture that grows before it. The view towards cosmic balance is the basic ideas of cities and houses in Java. Traditional settlements are the embryo of cities in Java coast, the spatial expression are the representation of people's idea towards the culture that they understand. To the people of Java, cosmological view is the effort to give direction to get to the "core": Worldly core, spiritual core. The core is the "ruler", "energy", "magnet", that ties in an abstract way, as well as becomes an "orientation" or director to the people. The journey of time and events has led to the shifts in the traditional views of the coastal area.

People of Kudus Kulon, especially in the area around Mosque Al-Aqsa are merchants and santri community (Fig. 1). Their main profession is as merchants or business owners, they are Puritan Islamic believer with Sunan Kudus as their central role model. The social bonding among them is very strong and it has dependency to be exclusive against the outside society. The cultural character of this society is pictured in the built environment, be it in the scale of housing, housing complex, or the environment (Sarjono, 1996). In accordance to Rapoport's opinion, that house is the main elements of settlement is the result of people's cooperation that in the physical statement is very much influenced by the socio-cultural factor from said people (Rapoport, 1982; 2005). The architectural visual of houses in Kudus might be one of the most interesting shapes in Indonesia. It is shown by he pattern of housing complex with the orientation and unique access, as well as the existence of mosque as the center of activity (Sarjono, 1996).

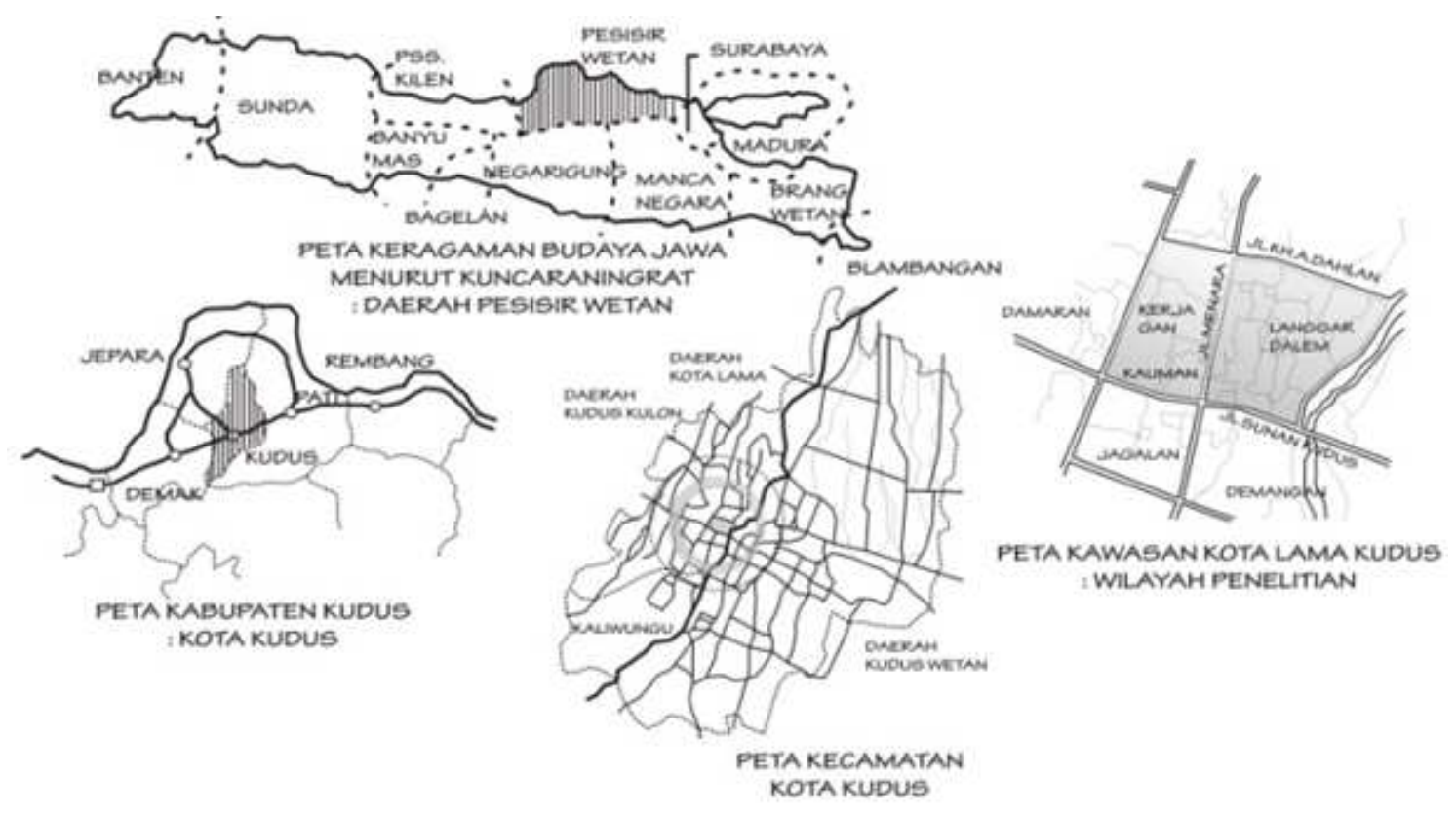

Fig. 1. Research location is the settlement area of Kampung Kauman Kudus Kulon (source of map: Sarjono, 1996) 


\subsection{Methods}

In this research, interpretative approach is conducted, centering the attention to the many concrete form of cultural meaning (ideographic). As a means, the first thing to be used is the method of historical interpretation. Secondary sources are needed to reconstruct the history of development in the important parts ofresearch area. These sources are textual scripts, babad (ancient document). Aside of that, several primary sources are also dug up to strengthen the arguments. To clarify the explanations regarding morphology and spatial condition of the city, ancient maps are used, or archeological data, as well as images and sketches that were made during the colonial era, or materials that were often published and used by public and the results of archeological researches, architectural researches that were done by individuals or by instances. Further reasearh also used the method of architecture semiotics, reading the text from Kudus Kulon to explore the social-cultural dimension that would investigate the social process in the society. Semioticarchitecture places architecture in a sign system that obeys certain rules. Urban space is comprised from sistem of signs that is regulated by codes. It has to be understood. This method is expected to be able to read and give interpretation about architectural signs in the tradition of living in Kudus Kulon. The research completes with graphic analysis so that the field data of spatial-architecture presented in a graphic model, site plan, sketch.

\section{RESULTS}

The result of research is four concepts, each part describes bellow.

\subsection{Center and Orientation}

Traditional settlement is the embodiment of cosmic harmony that is far from chaos (Budiharjo, 2007). At the beginning, the settlement pattern was structured at Masjid Agung (Grand Mosque) in the setting of 'mancapat' concept; four wind directions meeting in one point, right at the location of the mosque (symbol of connector between micro and macro cosmos), to the southern direction connects to the royal palace as a symbol of controller/leader of the micro cosmic world in the purpose of micro cosmos; meanwhile in the East-West axis, marketplace and settlements are located as the symbol of worldliness. These two axis combines between (1) 'terrestrial energy' working in the East-West as the symbol of worldliness, the process of human since the birth to the death; and (2) 'celestial energy', working in the North-South axis, the symbol of heavenly life (macro cosmic) that is depicted by the secular and spiritual leader through the media of the Masjid Agung with terraced roof or tajuk (in correlation with the holy Hindu building meru, or referring to the imaginary mountain ofMahameru, meaning the holy mountain (Prijotomo, 1985; Tjahjono, 1989). This idealism is not different with the concept of cosmic city Demak with its identity as Coastal Java city, seemingly simpler with the domination of the role of Masjid Agung as the symbol of connector between macro and micro cosmos. The cosmic city of Coastal Java is the embodiment of harmonization between macro cosmos and micro cosmos that are simpler and the containing substance is the egalitarian Islam. The pressure of modernization-capitalization of the center of the city gives impact to both the social and physical life. This is suspected to have moved the position of Alun-alun (Javanese central public space) in the city development. Define abbreviations and acronyms the first time they are used in the text, even after they have been defined in the abstract. Do not use abbreviations in the title or headings unless they are unavoidable.

Some other evidences can be seen from the position of the banyan tree in said location. The concept of Java "mancapal" city seems to be implemented in Kudus (Fig. 2). The changes that Old Kudus experienced, with the loss of Alun-alun and its replacement to business central is an indication of the shift in cosmic view. Social changes happened, but the daily life in Kudus Kulon is still colored with religious spirit in a relatively homogenous society; especially after the Dutch developed Eastern Kudus in the middle of the 19th century. Slowly, the area in Kudus Kulon is penetrated with other ethnicities, such as Chinese, making the structure of the community more heterogenic, especially on the strategic location, which was in mainstreet of Sunan Kudus. Next, in the corner of mainstreet of Sunan Kudus, next to the location of the former alun-alun and temple of Kong $\mathrm{Hu} \mathrm{Cu}$.

Meanwhile the daily life of people of Kudus Kulon has an important role for Mosque Al-Aqsa, because it is the spirit that keeps the Mosque alive and developed to a unity of cultural institution with a role of "controlling the morality of the city center (Suprapti, 2008; Suprapti and Budihardjo, 2010; Suprapti, 2012).

The development of architecture in the Kudus Kulon area was very phenomenal, started at the end of the 15th century since the beginning of pre-Islamic era up to today. Significantly, Islam and Colonial Dutch had major impact in the development of the architecture. 


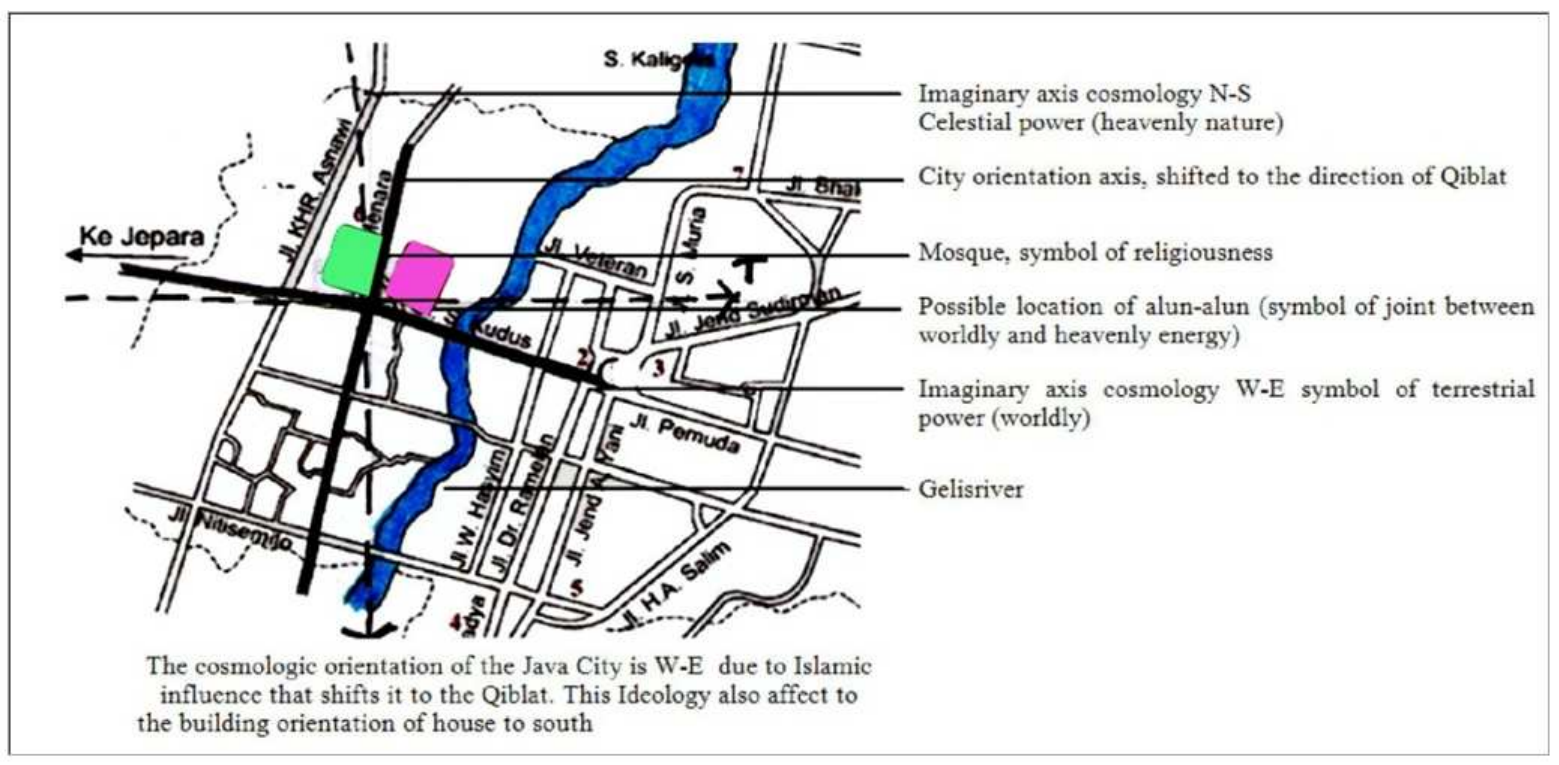

Fig. 2. The Influence of cosmology of spatial arrangement in old town Kudus Kulon

\subsection{Controlled Access}

The Javanese cosmology views the four wind direction was important, which was the East-WestNorth-South. These four wind direction creates two axis that meet in a middle point (center). The building orientation to the south is defined for people,the orientation to the north is for the rulers (Kings). People of Kudus Kulon respect to this view. In the development, many pencu houses that were built after the $19^{\text {th }}$ century became freer in choosing the building direction, be it to the north or to the other direction. The Concept of Controlled Access include bellow:

\subsubsection{Access of Buildings in the Mainroad}

Buildings in the main road, which was the northsouth axis and the east-west axis. The building access able reached from the south through front yard, because the main building is faced to the south. Thus, the access is straight from the main road. Houses that are located at north-south pole, the access is from east side to the building because the building is faced to south (Fig. 3-5).

\subsubsection{Access for Building Inside Villages}

Narrow aisles conects out side to inside village,wide around (1-1.5) $\mathrm{m}$. The street network is irregular/unplanned, only pedestrian and limited vehicle able pass through inside village. Several buildings has had to provide their own access to their houses (Fig. 6-10). Access of building inside villages include: (1) Direct access, in this case the road is located in front of the building (2) rotating access, because the road is located the northern side of the building and (3) walkthrough access, the owner of the building contributed the yard of house (private) as a public road.

Access is an important consideration for a common settlement. However in Kudus Kulon, access is not quite important. Building orientation is more interesting, which is facing to the south. The form of Kudus's house was very influenced by the idealism of Javanese cosmic. The demands of the main building to always face the south. It has impacts to the controlled building access. This controlled access is caused by factors includes: (1) Cosmological views, (2) an idealism to protect women and children, (3) demands of privacy, (4) limited areas, (5) close relations tend to closed up.

\subsection{Space of Agreement}

Space of agreement is the space that happens due to the agreement of several parties of the existence of people's participation in the spatial form for public needs, based on both written and unwritten agreements. This is based on: The thought of friendliness, neighborhood tolerance and kinship system. 


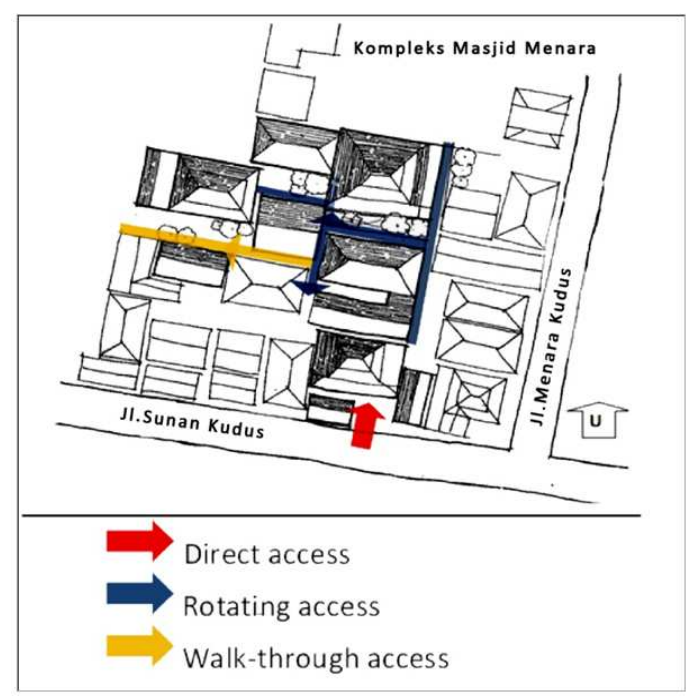

Fig. 3. Acess to building in kudus kulon in the mainroad

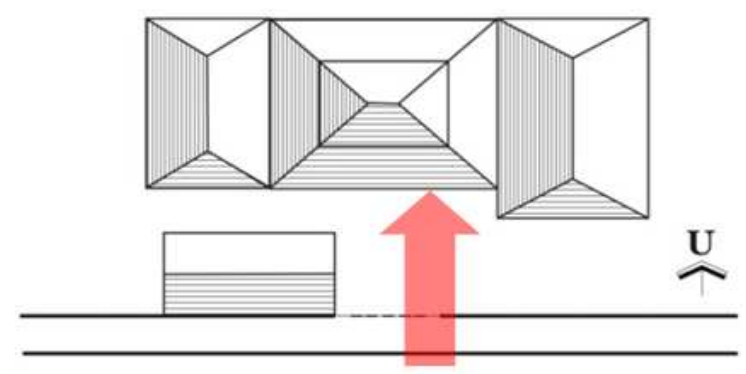

The house is facing to south to the main-road which is following ordering E-W pole

Fig. 4. Direct access to house from mainroad. The house is following ordering of east-west axis

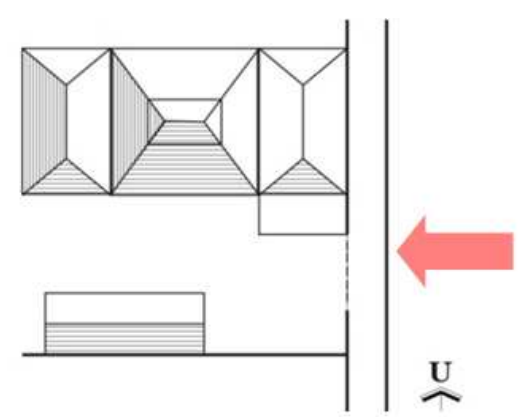

The house is facing to south to move along the side to the mainroad which is following ordering S-N pole

Fig. 5. Direct access to the house from the mainroad which is following ordering south-north

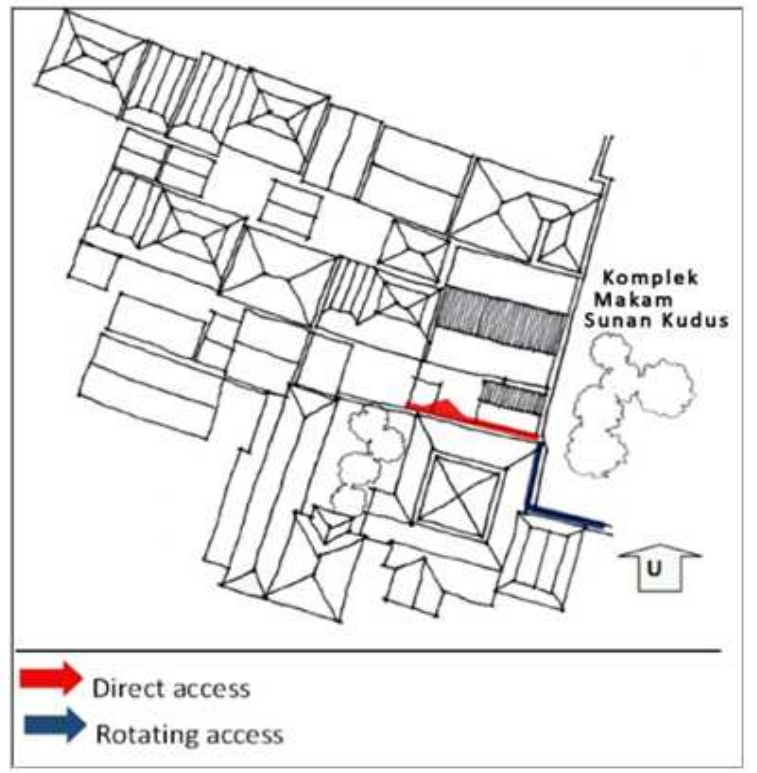

Fig. 6. Acess to building in kudus kulon inside the village

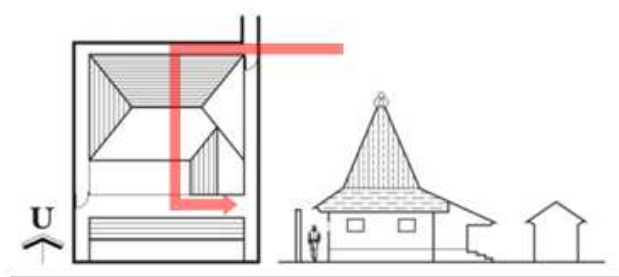

Because the house is facing the south, to access the front part, the house is surrounded by aisles or small roads. The front part of the house is accessed through a side door that penetrates the front yard

Fig. 7. Rotating acess to Mrs Anisa's family house inside the village
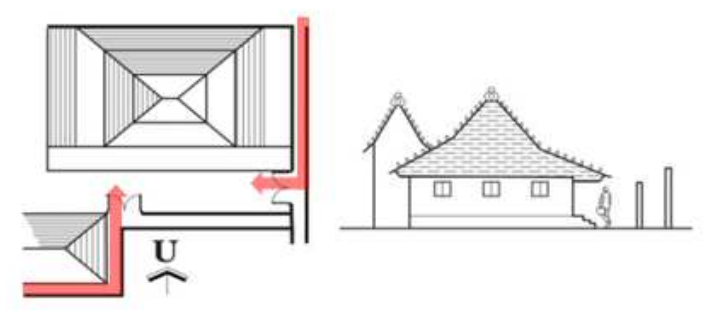

Because the house is facing the south, to access the front part, the house is surrounded by aisles or small roads. The front part of the house is accessed through a side door that penetrates the front yard

Fig. 8. Revolving acess to thehouse inside the village 
The space of agreement includes three categories: (1) House yard as walk-through road. It was based on the feeling of tolerance, friendliness and kinship; (2) mosque or mushala to socialize. People pray and socialize with their surrounding neighbors and (3) space for the ceremony of BukaLuwur,a big event which is annualy celebrated every year.

\subsection{High Level Privacy}

Houses are more oriented for individual need of the dwellers in relation with the function of protection from the many disturbances from the outside. In this case, several categories were found to be. This phenomenon is caused of background on their lifestyle ofbourgeois on the former of successfully trading period.

Affecting theconceptof high levelprivacysupported by six themes, which are explained as bellow:

Inheritance Agreement. Houses are more oriented for individual need of the dwellers in relation with the function of protection from the many external disturbances. In this case, several categories were found to be dividing inheritance is one thing that is unavoidable from an old building. This tradition is known as "nyusuki". This is an arrangement that is expected to be a solution in saving the traditional
Kudus heritage from selling it to an outside party. Space agreement in Javanese society based on local concept of ' guyub' (Purwanto, 2010). This concept complete withanti individualism. It makes city looks friendly, familiar, humble, belongs of society.

House plan with hierarchy-among sisir, kolah, pawon, dalem, there is hierarchy that puts dalem in the top (Fig. 11). Sisir is the building located at the frontside, which formerly function was a working place, because commonlly the profession of the people Kudus Kulon is merchants. Just now it used to continue the family business.

Nowadays, sisir can also change to a distinguish house completed with rooms of household. Among all of part of Kudus's house, (kolah, pawon, dalem, sisir), sosisir is most vulnerable part to changes (Fig. 11).

At least three things that shows the indication of dalemsacredness: (1) The orientation to the south, the location of kolah (toilet) in the frontside, so people sugested to have ablution before entering dalem. (2) The performace of dalem is covered of dominant pencu roof form. (3) The level of dalem is lifted up from the ground.

Tall fences wall-based on the feel of closing up from both the outside view and disturbance (Fig. 12). High window opening-outside view (Fig.

13).

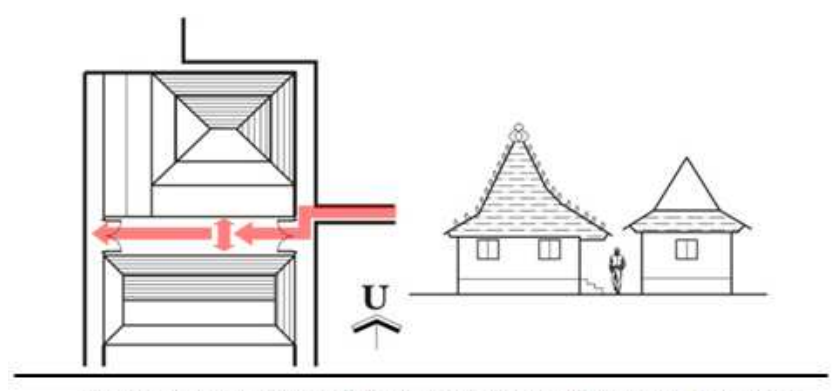

To access the part of the house that is facing to the south, there is an aisle that penetrates to the front yard. This family's front yard also an access road to the houses around it.

Fig. 9. Revolving access to Mr. Huda's family house

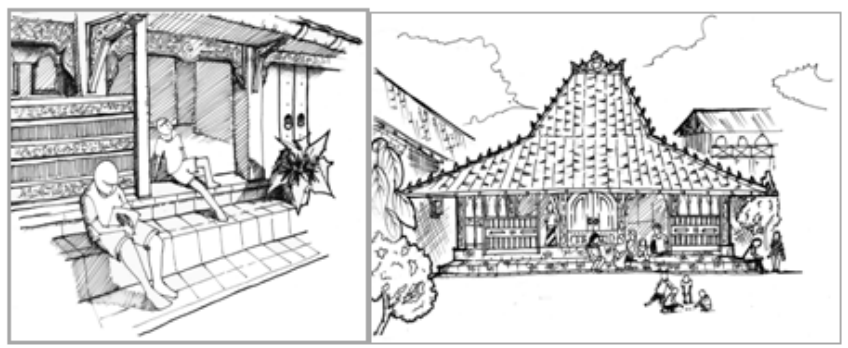

Fig. 10. Porch and front yard of Kudus's house are used to be a space socialstation of neighborhood (left). Front view of Kudus's house, dalem with pencu roof form (right). 


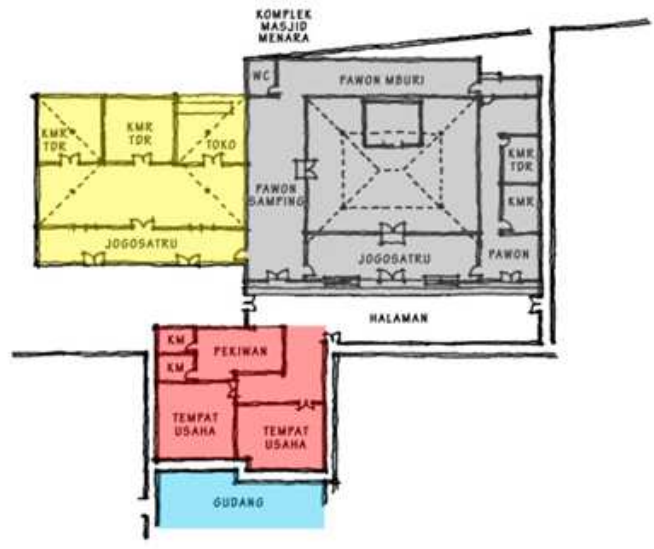

The development is to add Sisir (front part of the house). The figure shows that the building's spatial arrangement seems more complete if compared to the common Gebyok Pencu houses. This can be seen from the existence of Dalem (main house), three Powor (kitchens) in the left-right-back side, and the Sisir in the front. The west side of the main house is connected to another additional building. This building is complete enough as a house. complemented with Jogan, Jogosatriu three bedrooms, and bathroom. This building complex is also complemented with Sisir in the front that is used as business building. Separated from the road, there is a warehouse that used to function as a kretek cigarette factory

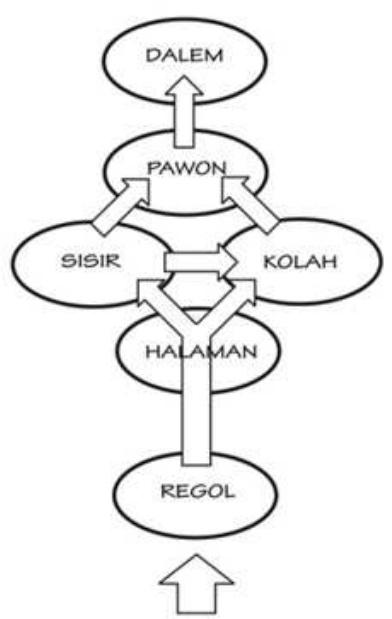

Fig. 11. Hierarchical of space of Kudus's house
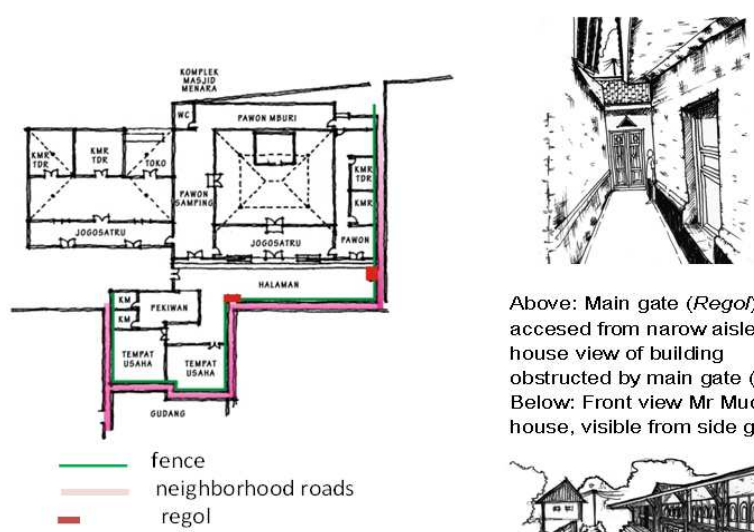

Above: Main gate (Regor) accesed from narow aisle to the house view of building obstructed by main gate (Regol). Below: Front view Mr Muchid.s house, visible from side gate

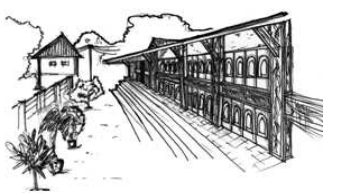

Fig. 12. Mr. H. Muhid family's House. This house is closed with tall fence wall. The access to the house is very controlled 


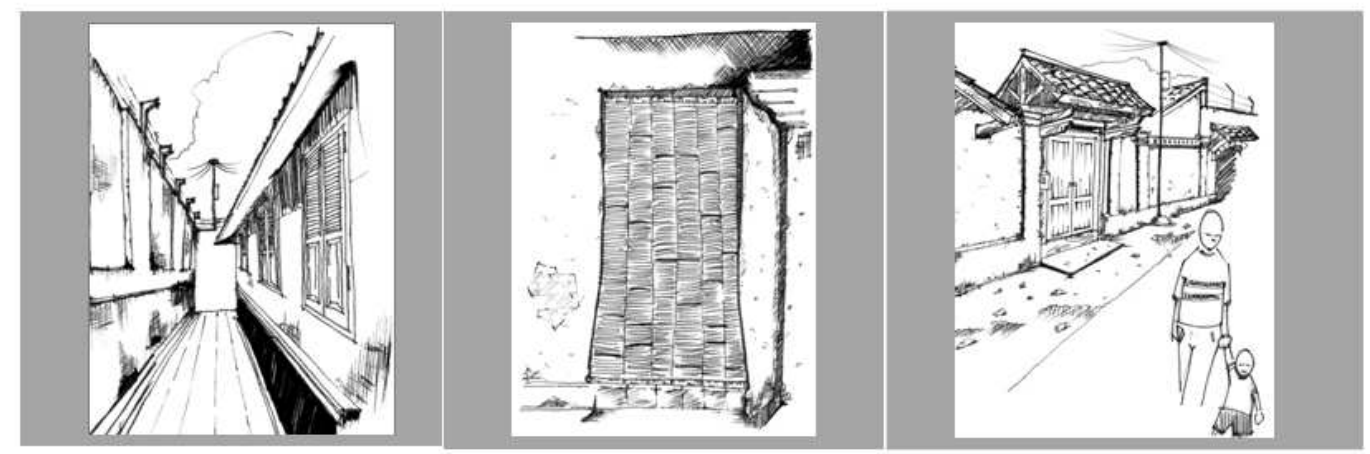

From the left to the right: The opening window located high enough from aisle floor, it makes people obstructed to watch inside the house; The bamboo screen in front of door as a visual filter; The closed gate (Regol) of high wall fence, the only way to go inside of the house

Fig. 13. The space elements constructing a high level privacy

\section{DISCUSSION}

\subsection{Organization of Space}

Organization of space of Kudus's house does not differ much from Java's house, that the house is a symbol of the node energy meeting between the terrestrial (earthly) energy axis which is propane and the celestial energy (deity) axis which is sacred (Tjahjono 1989; Prijotomo, 1985). Because the traditional Kudus's house oriented to the south which is the symbol of worldliness. The composition space are grouped on the basis of: (1). Jaba or preparation space, which includes regol (gate), Sisir (the space of working); (2.) Dalemwhich is core of house-includes: Jogosatru (guestroom), jogan (living room), sentong (bedroom), gendongan (praying room); (3) Pawon which is room of service. This organization of space show that there is an hierarchy in Kudus's house. It start from bottom layer those are regol and sisir = they has function as preparation room-usually covered to the roof shape of the gable (pelana), the floor level of this building is lowest. Then pawon (service), located at right side or left side of dalem core building, it covered with a gable roof shape or a pyramid roof shape-the function of building is to prepare a logistic of house-it has level floor higher thanregol, sisir and kolah. Further the top of hierarchy is dalem, has highest level floor, covered ofpencu, which is the towering form of the roof to the sky.

Apparently this is implementation hierarchy of Javanese life philosophy that is; "uripmungkanggomampirngombe"-live in the world just a moment of person drinks to quench the thirst, that in order to prepare for the next life, because they believe that the real purpose of human life is the eternal life of the Hereafter. The house is a symbol of this philosophythe house is the way to achieve the goals in nature paradise of eternity. In the mundane, human work is required, it is contained in building of sisir which is located on the front of the house. When finished working people want to rest at home, before going inside the house, that people must be cleaned up first with ablution in the kolah (toilet), which is located in front yard. Get into the house they will be rested and socialization to kinship (kinship), as well as a religious man, he would pray to God. Then later when the person dies, it will be taken to the tomb of cemetery that located in the northern settlement (the north is more sacred then the south).

In thissituation (Pearson, 2003) state that, peopleexperience their surrounding of setting through their five sense and their mere presence. In this space, they feel happy, comfort, secure, feel home to live in there.This term known as social cohesion.

\subsection{Space of Trancendental}

Giving Respect for ancestors manifested in the form of caring for ancestral grave for people Kudus. Mosque-Tomb concept is widely known in the Java society. It can be found in several Javanese ancient city, for example: The Great Mosque of Demak, Mantingan Mosque Al-Aqsa Mosque of Kudus, Kota Gedhe, this concept of culture influenced by Hinduism. The tomb of Sunan Kudus are located and treated well at behind MosqueAl Aqsa. Every year on 10'th Dzulhijah, people arrange ceremony of BukaLuwur which is meant to replace the netting of tomb with the new one. 
This event is done in the great festive, thousands people chanting prayers and scramble blessing of sacred objects. Sunan Kudus tomb visited by many local pilgrims who will perform an important events in their live. Considered sacred the tomb traditionally done since the beginning until nowadays (Wiryotomo, 1995; Triatmojo, 2010). The world view also believes that people live by honoring ancestors and worship with good. It will open a chance to live together with their ancestors in heaven-In this way they pay tribute to ancestors to connect the time between past, present and future. Mosque-Tomb-Settlement are the embodiment of transcendental space (Pangarsa, 2006) and proof of concept of Kudus society cosmology is still exist and applied in daily life can survive in the global culture. Such as (Pearson, 2003) say that the world view, territory, economy, greatly affect the integrity cosmology. People of Kudus world view and influence of the territory integrated as single unit. The internal capitalization of economic that performed by local actors serves as bumper for the pressure of external capitalization.

It seems that the Kudus Kulon settlement which completed with a strong control spatial pattern give an important affect to the viability of the culture cosmology. Thiis reminiscent of (Rapoport, 1982; 2005; Pangarsa, 2006; Purwanto, 2010; Triatmojo, 2010; Ramezani amd Hamidi, 2010) that the form of setting of settlement largely determine to the culture of society. A mix of economic capability, setting, the cultural cosmology, space has been made The character of the neighborhood is still strong and able to withstand the current exposure to globalization.

\subsection{Egalitarian Houses}

Traditional Kudus's house is an egalitarian house. The house was built and completed concepts of: The spatial arrangement, structure and ornaments. The house was destined to all member of society. In another word, there is no social hierarchy influence to the occupied of house. In Javanese houseknown joglo house as a specific one. Joglo has a space lay outhat arrangedbased on balancingofcelestial energy and terrestrial energy. Joglo house iscompletedwith specific toping of roof. This toping ofroof of joglo has adopted and modified to be toping of roof of pencu in Kudus traditional house. Different tothe Javanese joglo that is more destined to the royals. This can be seen from the building spatial arrangement plan.

\subsection{Changes in Traditional Kudus Houses}

The beauty of pencu roof form (Fig. 10) is really worth the complication of its maintenance. In the modern era development, people from the outside really enjoy this house shape, but ironically the local people seem to be very burdened with the large cost of maintaining them. In the modern era, there is a tendency in the people to choose another shape of roofing that is considered simpler like pyramid saddle roof. The meaning or historical value is no longer important when the people are faced with the reality of life that costs a lot.

Meanwhile, the layout of the traditional houses in Kudus is proven to be very flexible. Pawon (the kitchen), sisir (the front house) and kolah (the toilet in the front of house) can accommodate the needs of new spaces, making these parts of the house the first ones to be modified. The main house is the only part that seems to be sturdy with its shape, function, spatial arrangement plan, ornaments and aesthetic. If the main house is modified, then it is almost certain that the other parts of the building are changed too.

From the access side, this area is relatively unchanged. The road hierarchy and the controlled access to the building are two bumpers for the penetrations of outside influences. This is why newcomers are very reluctant to settle down in this area. This also enables the reservation of the area's originality. However, it is still possible that in the future, the rush of modernism and capitalism will get stronger and there will be penetrations in this area.

One of the most extreme changes is the change of building ownership of the main gebyog house to the hands of the people from outside of Kudus. In the present time, this often happens because this seems to be an alternative solution to the issue of inheritance. It seems like the idealism of Kudus Kulon's citizen is slowly shifted by the demands of materiality, away from the appreciation for local cultural history. This is quite concerning, because sooner or later the artifacts will disappear and it will threaten the local identity of the people in Kudus Kulon.

\section{CONCLUSION}

Differ to the concept of the most settlements where the main consideration is access, in Kudus Kulon, access is not more important than the southern-oriented buildings. This is due to their cosmological idealism. The homogenous and business-oriented people of Kudus Kulon contribute largely to the pattern of the settlements through the agreements of spaces. Business became a very important part in the life of this society, thus the 
sisir (the front building) becomes the part that is most vulnerable to change, while the dalem (main house) is a conservative part, yet often faced with extreme changes. The change in the traditional Kudus housing happens under the threat of modernization and capitalization. The threat towards building artifacts of gebyog houses will only take them away from their roots, because there are many outside investors that are very interested to these antique buildings. The existing artifacts are in dire need of protection, be it from the public or the private sector with commitments to the protection of cultural heritage.

The tradition of living of Kudus Kulon community shows the traditional compact urban concept existence. It had created a characterized place, since the strong social cohesion met to the specific setting background. This matter had gave an impressed space experiences that tie with the subject of space, to always feel the power of identity.The result of the research.

The government should pay attention seriously to protect cultural history artifacts of Kudus Kulon, which has a high value, from pressure of capitalization and the threat of antique hunter. They should stop the destruction of historic and culture artifact. The research result has contribute an scientific information about the change of local identity of Kudus Kulon.. Further for the next research, we recommend to get inventory of the artifacts and to empowering communities to be aware of the important role of preserving environment.

\section{ACKNOWLEDGEMENT}

This study is under Research Grant supported by Directorate Research and Servitude to Society of Directorate General of High Education Department Education and Culture Republic of Indonesia. A high gratitude to The Head of Architecture Department, Dean of Engineering Faculty, The Head of Research and Servitude to Society also The Head of Diponegoro University Indonesia.

\section{REFERENCES}

Budiharjo, E., 2007. Sejumlah Masalah Permukiman Kota. Bandung: Alumni, University of Michigan, ISBN-10: 9794140376, pp: 273.

Ekomadyo, S.A., 1999, Kajian Kota Islam Penelusuran antara Ide-Ide Kota dalam Sumber Hukum Islam dengan Pola Tata Letak Fisik Perkotaan yang Ada, Unpublished Thesis Program Magister Arsitektur, ITB Bandung.
Lombard, D., 2005. Nusa Jawa: Silang Budaya, Kajian Sejarah Terpadu, Bagian I: Batas-Batas Pembaratan. 1st Edn., PT Gramedia Pustaka Utama Jakarta-Paris. pp: 309.

Pearson, P.M. and C. Richard, 2003. Architecture and Order Approaches to Social Space, In: Tylor and Francis e- Library, Michael, P. and P.C. Richards (Eds.)., Routledge, ISBN-10: 1134728115, pp: 260.

Prijotomo, J., 1985. Ideal and Form of Javanese Architecture, Ohio Univ Pr (Trd), Jogyakarta, ISBN-10: 0821408178,

Purwanto, E., 2010. Rukun Kota (Ruang Kota Berbasis Budaya Guyub) Poros Tugu Pas Putih sampai dengan Alun-Alun Yogykarta. University of Gajah Mada, Jogyakarta, Indonesia.

Qurtuby, S., 2003. Arus Cina-Islam-Jawa: Bongkar Sejarah Atas Peranan Tionghoa Dalam Penyebaran Agama Islam di Nusantara abad XV and XVI 1st Edn., Kerjasama Inspeal Press dengan Perhimpunan Indonesia Tionghoa, ISBN10: 9799761603 , pp: 311.

Ramezani, S. and S. Hamidi, 2010. Privacy and social interaction in traditional town and contemporary urban design in Iran. Am. J. Eng. Applied Sci., 3: 18-24.

Rapoport, A., 1982. The Meaning of the Built Environment: A Nonverbal Communication Approach. 1st Edn., reprint, University of Arizona Press, ISBN-10: 0816511764, pp: 253.

Rapoport, A., 2005. Theory Social and Culture, Tylor and Francis MetapressCulture, Architecture and Design.

Sarjono, B.A., 1996. Rumah-Rumah di Kota Lama Kudus. Unpublished Thesis, Magister Teknik Arsitektur, Universitas Gajah Mada Yogyakarta.

Suprapti, A., 2008. The meaning of centre and orientation upon the traditional settlement in semarang. Proceedings of the NURI International Conference, Manado.

Suprapti, A., 2012. Kontrol protektif pada ruang bermukim komunitas kauman semarang. $\mathrm{PhD}$ Thesis, Universityof Diponegoro Indonesia.

Suprapti, B.A. and E. Budihardjo, 2010. Ethnography architecture in kampong kauman semarang, a comprehension of cultural toward space. Am. J. Eng. Applied Sci., 3:576-587.

Tjahjono, G., 1989. Cosmos, Centre and Duality in Javanese Architectural Traditional: The Symbolic Dimentions of House Shapes in Kota Gede and Surroundings. 1st Edn., University California Berkeley, pp: 748. 
Tjandrasasmita, U., 2000. Pertumbuhan dan Perkembangan kota-kota Muslim di Indonesia dari abad XIII Sampai XVIII Masehi. 1st Edn., The University of Michigan, pp: 231.

Triatmojo, S., 2010. Pemupakatan dan Desakralisasi Ruang di Permukiman Kauman Yogyakarta, Unpublished Dissertation, in partial fulfillment of the requirements for the degree of Doctor University of Gajah Mada, Jogyakarta, Indonesia.
Wertheim, F.W., 1999. Masyarakat Indonesia Dalam Transisi: Studi Perubahan Sosial. 1st Edn., PTTiara Wacana Yogya, Yogyakarta.

Wiryotomo, P.B.A., 1995. Seni Bangunan dan Seni Binakota di Indonesia, Jakarta, PT Gramedia Pustaka Utama. 